\title{
Microarray-based analysis of microRNA expression in breast cancer stem cells
}

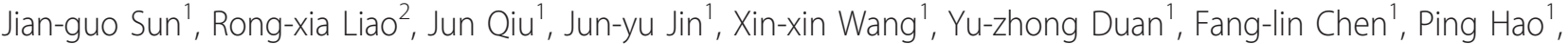 \\ Qi-chao Xie ${ }^{1}$, Zhi-xin Wang ${ }^{1}$, De-zhi Li ${ }^{1}$, Zheng-tang Chen ${ }^{1 *}$, Shao-xiang Zhang ${ }^{3^{*}}$
}

\begin{abstract}
Background: This study aimed to determine the miRNA profile in breast cancer stem cells (BCSCs) and to explore the functions of characteristic BCSC miRNAs.

Methods: We isolated ESA ${ }^{+} \mathrm{CD} 44^{+} \mathrm{CD} 24^{- \text {-low }}$ BCSCs from MCF-7 cells using fluorescence-activated cell sorting (FACS). A human breast cancer xenograft assay was performed to validate the stem cell properties of the isolated cells, and microarray analysis was performed to screen for BCSC-related miRNAs. These BCSC-related miRNAs were selected for bioinformatic analysis and target prediction using online software programs.

Results: The ESA ${ }^{+} \mathrm{CD} 44^{+} \mathrm{CD} 24^{- \text {/low }}$ cells had up to 100- to 1000-fold greater tumor-initiating capability than the MCF-7 cells. Tumors initiated from the ESA ${ }^{+} \mathrm{CD} 44^{+} \mathrm{CD} 24^{- \text {llow }}$ cells were included of luminal epithelial and myoepithelial cells, indicating stem cell properties. We also obtained miRNA profiles of ESA ${ }^{+} C D 44^{+} C D 24^{-/ l o w} B C S C s$. Most of the possible targets of potential tumorigenesis-related miRNAs were oncogenes, anti-oncogenes or regulatory genes.

Conclusions: We identified a subset of miRNAs that were differentially expressed in BCSCs, providing a starting point to explore the functions of these miRNAs. Evaluating characteristic BCSC miRNAs represents a new method for studying breast cancer-initiating cells and developing therapeutic strategies aimed at eradicating the tumorigenic subpopulation of cells in breast cancer.
\end{abstract}

\section{Background}

Breast cancer is one of the most common cancers in women and poses a threat to women's health. Al-Hajj's research in 2003 has shown that breast cancer stem cells $\left(\mathrm{ESA}^{+} \mathrm{CD} 44^{+} \mathrm{CD} 24^{-/ \text {low }}, \mathrm{BCSCs}\right)$ possessing the stem cell properties of self-renewal and multi-directional differentiation are the most fundamental contributors to drug resistance, recurrence and metastasis of breast cancer [1]. Previous studies in both breast cancer cells and tissues have shown that breast cancer stem cells are cells with an $\mathrm{ESA}^{+} \mathrm{CD} 44^{+} \mathrm{CD} 24^{-/ \text {low }}$ phenotype [2,3]. We based this study on the previous findings on breast cancer stem cell phenotype and finally proved it. Research

\footnotetext{
* Correspondence: zhengtangchen@yahoo.com.cn; sunjianguo1972@yahoo. com.cn

${ }^{1}$ Cancer Institute of People's Liberation Army, Xinqiao Hospital, Third Military Medical University, Chongqing, 400037, China

${ }^{3}$ Department of Anatomy, College of Medicine, Third Military Medical University, Chongqing, 400038, PR China

Full list of author information is available at the end of the article
}

focusing on BCSCs is likely to bring revolutionary changes to our understanding of breast cancer; however, a multitude of unresolved issues remain with regard to the molecular basis of carcinogenesis. For example, what is the full nature of the involvement of BCSCs in the molecular mechanisms of tumorigenesis? Are microRNAs (miRNAs) involved in the function of BCSCs? If so, how are they involved?

As an important class of regulatory noncoding RNAs, miRNAs have been shown to play important roles in the committed differentiation and self-renewal of embryonic stem cells and adult stem cells [4]. The current release (10.0) of miRBase contains 5071 miRNA loci from 58 species [5]. miRNAs can act as oncogenes or anti-oncogenes and are involved in tumorigenesis, including chronic lymphocytic leukaemia, paediatric Burkitt's lymphoma, gastric cancer, lung cancer and large-cell lymphoma [6-8]. In Homo sapiens, miRNAs (1048 sequences in miRBase 16 , Sep $\left.10^{\text {th }}, 2010\right)$ regulate more than one-third of all genes, bringing hope to studies of 
cancer stem cells http://www.mirbase.org/. Thus, the identification of cancer stem cell-related miRNAs would provide valuable information for a better understanding of cancer stem cell properties and even the molecular mechanisms of carcinogenesis. Here, we investigated the miRNA expression profiles of $\mathrm{ESA}^{+} \mathrm{CD} 44^{+} \mathrm{CD} 24^{-/ \text {low }}$ BCSCs from the MCF-7 cell line.

\section{Methods}

\section{Fluorescence-activated cell sorting (FACS) of BCSCs}

The human breast cancer cell line MCF-7 was cultured in minimal essential medium (MEM) (Invitrogen, America). Cells in $\log$ phase were digested with $0.25 \%$ trypsin (Gibco, America) and washed with PBS, then stained with FITC-conjugated anti-ESA, APC-conjugated antiCD44 and PE-conjugated anti-CD24 (BD PharMingen, America). After $30 \mathrm{~min}$ incubation, the cells were washed three times, and FACS (MoFlo, America) was performed to isolate the $\mathrm{ESA}^{+} \mathrm{CD} 44^{+} \mathrm{CD} 24^{-/ \text {low }}$ cells.

\section{Colony-forming assay of BCSCs}

The isolated $\mathrm{ESA}^{+} \mathrm{CD} 44^{+} \mathrm{CD} 24^{-/ \text {low }}$ lineage ${ }^{-}$cells were suspended in MEM supplemented with 1\% FBS and washed twice with the same medium. The medium was then replaced with EpiCult ${ }^{\mathrm{tw}}-\mathrm{B}$ medium (Stemcell technologies, Canada) supplemented with $5 \%$ FBS. Subsequently, $1 \times 10^{4}$ BCSCs were seeded onto $2 \times 10^{4}$ irradiated NIH/3T3 feeder cells in 24-well plates. The mouse embryonic fibroblast cell line NIH/3T3 was cultured in DMEM (Invitrogen). As feeder layer cells, $\mathrm{NIH} / 3 \mathrm{~T} 3$ cells in $\log$ phase were exposed to ${ }^{60} \mathrm{Co}$ at $50 \mathrm{~Gy}$. The medium was replaced again with serum-free EpiCult ${ }^{\mathrm{m}}-\mathrm{B}$ medium at $24 \mathrm{hr}$ after seeding, and the cells were incubated in $5 \% \mathrm{CO}_{2}$ at $37^{\circ} \mathrm{C}$. The cells were supplied with fresh medium every 3 days, and colonies were observed under a microscope after 7-10 days.

\section{Human breast cancer xenograft assay}

Eight-week-old female NOD/SCID mice were given 2.5 Gy of ${ }^{60} \mathrm{Co}$ radiation, and tumor cell injections were performed 1 day after irradiation. The tumor cells were suspended in $0.2 \mathrm{ml}$ of IMDM containing 10\% FBS and injected into the mammary fat pad at the left armpit. The mice in the test group were injected with $0.5 \times 10^{3}$, $1 \times 10^{3}, 5 \times 10^{3}, 1 \times 10^{4}$ or $5 \times 10^{4} \mathrm{ESA}^{+} \mathrm{CD} 44^{+} \mathrm{CD} 24^{-1}$ low cells isolated by FACS, whereas the mice in the control group were injected with $1 \times 10^{4}, 5 \times 10^{4}, 1 \times 10^{5}$, $5 \times 10^{5}$ or $1 \times 10^{6}$ MCF-7 cells. Three mice in each group were inoculated with the same amount of cells. The mice were observed for tumor growth every 10 days over 8 weeks and then sacrificed by cervical dislocation. Single cell suspensions were obtained according to our previously published protocol [9]. Subsequently, $\mathrm{ESA}^{+} \mathrm{CD} 44^{+} \mathrm{CD} 24^{-/ \text {low }}$ cells were isolated from the xenograft tumor cells by FACS and injected into the mammary fat pad as described above. All animal procedures were carried out with the approval of the Animal Ethics Committee of the Third Military Medical University.

\section{Immunostaining of tissue sections}

Tumor tissue slides were prepared for immunohistochemistry. Epithelial membrane antigen (EMA) and smooth muscle actin (SMA), markers of luminal epithelial and myoepithelial cells, respectively, were used for immunostaining according to our previously published protocol [9]. Rabbit polyclonal anti-EMA or anti-SMA antibodies (dilution 1:500; Santa Cruz, CA) were used.

\section{Microarray Fabrication and miRNA hybridisation}

Both miRNA microarray fabrication and hybridisation were performed as described previously [9]. Our miRNA microarray included 517 mature miRNA sequences and 122 published predicted miRNA (Pred_miR) sequences [10]. For each sample, two hybridisations were carried out, and each miRNA probe had three replicate spots on the microarray. Significance Analysis of Microarrays (SAM, version 2.1) was performed using a two classunpaired comparison in the SAM procedure.

\section{Real-time RT-PCR}

All primers were designed using Primer Express version 2.0 (Applied Biosystems, Foster City, CA). We followed the protocol of Chen et al. for primer design and realtime RT-PCR [11]. The primers were $5^{\prime}$-ctcgcttcggcagcaca-3' and 5'-aacgcttcacgaatttgcgt-3' for the U6 small nuclear RNA, which was used as an internal control. The analysed miRNAs included miR-122a, miR-188, miR-200a, miR-21, miR-224, miR-296, miR-301, miR-31, miR-373* and miR-200C.

\section{Bioinformatic analysis and target prediction}

Three online software programs, miRanda http://microrna.sanger.ac.uk, picTar http://www.ncrna.org/KnowledgeBase/link-database/mirna_target_database, and targetscan http://www.targetscan.org, were used for bioinformatic analysis and target prediction for the miRNAs.

\section{Results}

\section{Isolation and culture of $\mathrm{ESA}^{+} \mathrm{CD} 44^{+} \mathrm{CD} 24^{-/ \text {low }}$ cells}

The expression of ESA, CD44 and CD24 in MCF-7 cells were analyzed by flow cytometry. A $1-2 \%$ frequency of $\mathrm{ESA}^{+} \mathrm{CD} 44^{+} \mathrm{CD} 24^{-/ \text {low }^{\prime}}$ lineage ${ }^{-}$cells was observed, and the cells were isolated by flow cytometry (Figure 1A). Using FACS sorting, this subpopulation of cells was highly purified (98-99\% purity). To assess the clonogenic potential of these BCSCs, the cells were seeded into 


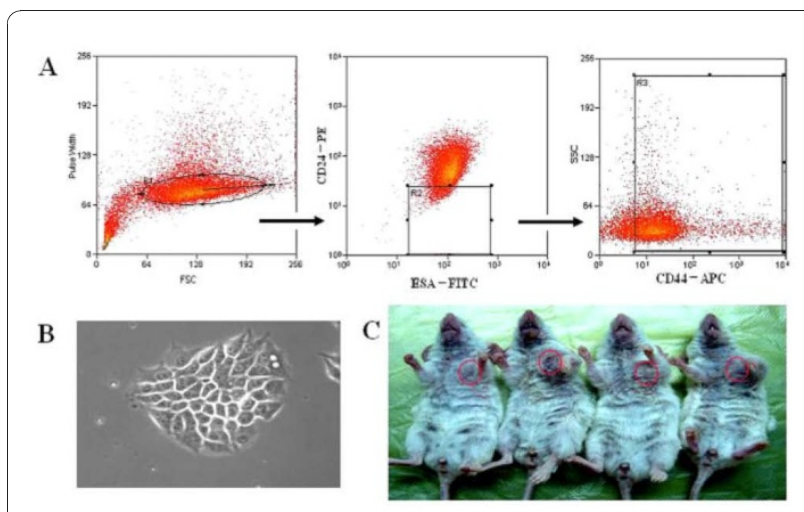

Figure 1 Stem cell properties of $\mathrm{BCSC}$. ESA ${ }^{+} \mathrm{CD} 44^{+} \mathrm{CD} 24^{-1}$ lowlineage human BCSCs (corresponding to $1.5 \%$ of cancer cells) were isolated by flow cytometry (A). Under an inverted phase contrast microscope, the $\mathrm{ESA}^{+} \mathrm{CD} 44^{+} \mathrm{CD} 24^{- \text {/low }}$ grew into globular colonies (B). Xenograft tumors in NOD/SCID mice are shown (C). From left to right, tumors developed from $5 \times 10^{5}$ and $5 \times 10^{6}$ MCF-7 cells and from $5 \times 10^{3}$ and $5 \times 10^{4}$ BCSCs.

24-well plates on top of irradiated NIH/3T3 feeder cells. At day 3, the number of adherent cells increased, and three to five epithelioid colonies formed. At day 6, the colonies continued to expand and spread stereoscopically. After 10 days in culture, most of the colonies contained more than 50 cells and were surrounded by floating or dead NIH/3T3 cells. Under an inverted phase contrast microscope, the $\mathrm{ESA}^{+} \mathrm{CD} 44^{+} \mathrm{CD} 24^{-/ \text {low }}$ cells were observed to grow into globular colonies (Figure 1B). These cells showed no special morphological changes, however, compared with MCF-7 cells.

\section{Stem cell properties of $\mathrm{ESA}^{+} \mathrm{CD} 44^{+} \mathrm{CD} 24^{-/ \text {low }}$ cells}

We injected isolated $\mathrm{ESA}^{+} \mathrm{CD} 44^{+} \mathrm{CD} 24^{-/ \text {low }}$ cells and MCF-7 cells (as a control) subcutaneously into the armpits of NOD/SCID mice. After 8 weeks, the MCF-7 cells gave rise to new tumors when $\geq 5 \times 10^{5}$ cells were injected but failed to do so at lower doses $\left(1 \times 10^{5}\right.$ cells). In contrast, the $\mathrm{ESA}^{+} \mathrm{CD} 44^{+} \mathrm{CD} 24^{-/ \text {low }}$ cells formed tumors in three of three, three of three and one of three animals when $5 \times 10^{4}, 1 \times 10^{4}$, and $5 \times 10^{3}$ cells were injected, respectively. Tumor specimens were retrieved and subsequently passaged into recipient mice. At 8 weeks after inoculation, three of three, three of three, and two of three recipient animals formed tumors when $5 \times 10^{4}, 1 \times 10^{4}$ and $5 \times 10^{3}$ cells were injected, respectively. Tumors were also observed in one of three animals in the control group when $5 \times 10^{5}$ cells were injected; however, $5 \times 10^{4}-1 \times 10^{5}$ cells failed to form tumors in the control group (Table 1 Figure 1C). These data indicate that $\mathrm{ESA}^{+} \mathrm{CD} 44^{+} \mathrm{CD} 24^{-/ \text {low }}$ cells are tumorigenic and have up to 100 - to 1000 -fold greater tumor-initiating capability than MCF-7 cells.
In addition, we tested ESA+CD44+/CD24- subpopulation variability in the murine model by FACS analysis. ESA+CD44+/CD24- subpopulation in unsorted MCF-7 xenografts remained to be $1-2 \%$, showing little change. By contrast, ESA+CD44+/CD24- subpopulation in sorted MCF-7 xenografts were significantly enriched to $4-5 \%$.

Tumor tissue slides were prepared for $H \& E$ staining and immunohistochemical staining. The tumors in the BCSCs group were positive for both EMA and SMA, indicating that they were included of both luminal epithelial and myoepithelial cells. On the other hand, the tumors in the MCF-7 control group were positive for EMA, but negative for SMA, indicating that they were included of luminal epithelial cells, but not myoepithelial cells (Figure 2).

\section{MiRNA expression profiles in $\mathrm{ESA}^{+} \mathrm{CD} 44^{+} \mathrm{CD} 24^{-/ \text {low }} \mathrm{BCSCs}$}

For each cell type, the hybridisation reaction was repeated twice. The internal control U6 snRNA spots on all of the microarrays showed consistent signal strength, and the signal intensity of all of the detected spots on the replicate microarrays indicated high correlation coefficients $(\mathrm{R}=0.9747 \pm 0.0304)$, highlighting the reproducibility of hybridisation between the replicate microarrays(Additional file 1 Figure S1). There were 147 miRNAs in the MCF-7 cells and 102 miRNAs in the BCSCs, including predicted miRNAs (PRED_MIR), which gave a signal value above 800. The previously reported miRNA expression profile of MCF-7 cells (Ambion, USA) included 41 miRNAs (signal value $\geq++$ ). Among those miRNAs, 34 were also detected in our study, indicating a concordance rate of $82.9 \%$ (Additional file 1Table S1 S2 \& S3). We compared the miRNA expression profiles of BCSCs and MCF-7 cells using a normalisation factor and clustering. A miRNA was defined as differentially expressed when a value of $\mathrm{p}<0.05$ was obtained. We identified 25 differentially expressed miRNAs that fell into two groups (fold change $\geq 4$ ). In the first group, there were 19 miRNAs with an expression level that was four times higher in BCSCs than in MCF-7 cells: miR-122a, miR-152, miR-212, miR-224, miR-296, miR-31, miR-373*, miR-489, PRED_MIR127, PRED_MIR154, PRED_MIR157, PRED_MIR162, PRED_MIR165, PRED_MIR191, PRED_MIR207, PRED_ MIR219, PRED_MIR246, PRED_MIR88 and PRED_MIR90. In the second group, there were six miRNAs with an expression level that was four times lower in BCSCs than in MCF-7 cells: miR-200a, miR-301, miR-188, miR-21, miR-181d and miR-29b.

\section{Validation of microarray differential expression data by real-time RT-PCR}

We performed real-time RT-PCR for 10 miRNAs: miR122a, miR-188, miR-200a, miR-21, miR-224, miR-296, 
Table 1 Human breast cancer xenograft assay of the $\mathrm{ESA}^{+} \mathrm{CD} 44^{+} \mathrm{CD} 24^{-/ / 0 w}$ population

\begin{tabular}{|c|c|c|c|c|c|c|c|c|}
\hline \multirow[b]{2}{*}{ Injected cell number } & \multicolumn{8}{|c|}{ Tumors-developed mice/cell-injected mice } \\
\hline & $1 \times 10^{6}$ & $5 \times 10^{5}$ & $1 \times 10^{5}$ & $5 \times 10^{4}$ & $1 \times 10^{4}$ & $5 \times 10^{3}$ & $1 \times 10^{3}$ & $5 \times 10^{2}$ \\
\hline \multicolumn{9}{|l|}{ MCF-7 cell line } \\
\hline Unsorted MCF-7 & $3 / 3$ & $1 / 3$ & $0 / 3$ & $0 / 3$ & $0 / 3$ & - & - & - \\
\hline $\mathrm{ESA}^{+} \mathrm{CD} 44^{+} \mathrm{CD} 24^{- \text {llow }} \mathrm{BCSCS}$ & - & - & - & $3 / 3$ & $3 / 3$ & $1 / 3$ & $0 / 3$ & $0 / 3$ \\
\hline \multicolumn{9}{|l|}{ Xenograft tumor cells } \\
\hline Unsorted breast cancer cells & $3 / 3$ & $1 / 3$ & $0 / 3$ & $0 / 3$ & - & - & - & - \\
\hline $\mathrm{ESA}^{+} \mathrm{CD} 44^{+} \mathrm{CD} 24^{-1 / \mathrm{low}} \mathrm{BCSCs}$ & - & - & - & $3 / 3$ & $3 / 3$ & $1 / 3$ & $0 / 3$ & $0 / 3$ \\
\hline
\end{tabular}

MCF-7 cells gave rise to new tumors when at least $5 \times 10^{5}$ cells were injected per animal but failed to do so at lower doses ( $10^{5}$ cells). By contrast, ESA ${ }^{+}$CD44 ${ }^{+} \mathrm{CD} 24^{- \text {/low }}$ cells formed tumors when $5 \times 10^{3}$ cells were injected per animal. Tumor specimens were retrieved and subsequently passaged into recipient mice, and the same results were observed.

miR-301, miR-31, miR-373* and miR-200C. As a negative control, miR-200C did not show obvious difference in our study. The experiments were repeated three times each. Eight of the ten miRNAs tested gave realtime RT-PCR results that were concordant with the microarray data, with miR-296 being the only exception, indicating a concordance rate of $88.89 \%$. The electrophoretogram showed clear and specific bands for all of the real-time RT-PCR reactions, and all the amplification curves in the PCR reactions were distinct (Figure 3A). Part of amplification curves for miR-188, miR-200a miR301 and miR-31 are shown in Figure 3B. The Q-RT-PCR results for the $10 \mathrm{miRNAs}$ tested were $6.344 \pm 0.402$, $0.226 \pm 0.513,0.086 \pm 0.514,0.071 \pm 0.503,14.175 \pm$ $2.033,0.334 \pm 0.587,0.066 \pm 1.008,2.816 \pm 0.328,6.684$ \pm 0.548 and $0.345 \pm 0.531$ (expressed as the relative ratio between the Q-RT-PCR results for BCSCs and MCF-7 cells \pm standard deviation). Despite little difference in the microarray results, the expression of miR-200c was found to be no more than three times lower in BCSCs than in

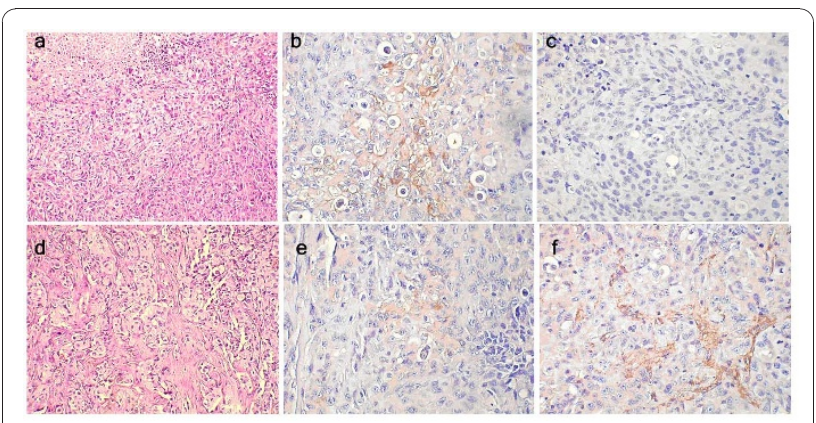

Figure 2 MiRNAs expression profiles by microarray with Q-RTPCR verification. Haematoxylin and eosin (H\&E) staining and immunohistochemical staining are shown on pathology sections of tumors implanted in NOD/SCID mice. In a, b and c, the staining showed a single cell type by H\&E (100x), EMA-positive cells (200x) and SMA-negative cells (200x), respectively, for the MCF-7 group. In $\mathrm{d}$, e and $\mathrm{f}$, the staining showed at least two cell types by H\&E (100x), EMA-positive cells (200x) and SMA-positive cells (200x), respectively, for the BCSC group.
MCF-7 (Figure 3CTable 2). Thus, the miRNA expression profiles of the BCSCs were confirmed by Q-RT-PCR.

\section{Bioinformatic analysis and preliminary functional analysis of BCSC-related miRNAs}

Chromosome localisation, sequence analysis and target prediction of the miRNAs were carried out using online software programs. Potential tumorigenesis-related miRNAs and their possible targets were analysed. Most of these targets were oncogenes, anti-oncogenes or regulatory genes involved in miRNA processing, transcriptional regulation, signal transduction, apoptosis regulation and stem cell function and maintenance, etc. For example, there were 161 potential targets of miR122a, including RAD21, G3BP2, CDC42BPB, SP2, GPR172B, GPR172A, MAP3K3, DR1, KHDRBS1, MAP3K12, CCNG1 and DICER1. These potential targets included oncogenes, transcription factors and genes related to DNA repair, cell cycle regulation, miRNA processing and signal transduction. The gene encoding miR-21 was located on chromosome 17 , and there were 175 potential targets of miR-21, including PLAG1, PDCD4, SKI, BCL2, STAT3, PITX2, HBP1, ELF2, E2F3, SPRY1, CDC25A, N-PAC, EIF1AX, EIF2C2, RAB11A, RAB6A, RAB6C, RASGRP1, RHOB, RASA1, TPM1, TGFBI and TNFSF6, which exist exclusively in humans, mice, dogs, chimps and chickens. These potential targets included pleiomorphic adenoma genes, transcription factors, oncogenes, anti-oncogenes, and genes related to miRNA processing and signal transduction (Additional file 1 table $\mathrm{S} 4$ ).

\section{Discussion}

There is increasing evidence for the involvement of miRNAs in mammalian biology and breast cancer. For instance, the levels of MiR-206 have been found to be higher in ERalpha-negative MB-MDA-231 cells than in ERalpha-positive MCF-7 cells [12], and enforced expression of miR-125a or miR-125b leads to coordinate suppression of ERBB2 and ERBB3 in the human breast cancer cell line SKBR3 [13]. Furthermore, MiR-27b, 


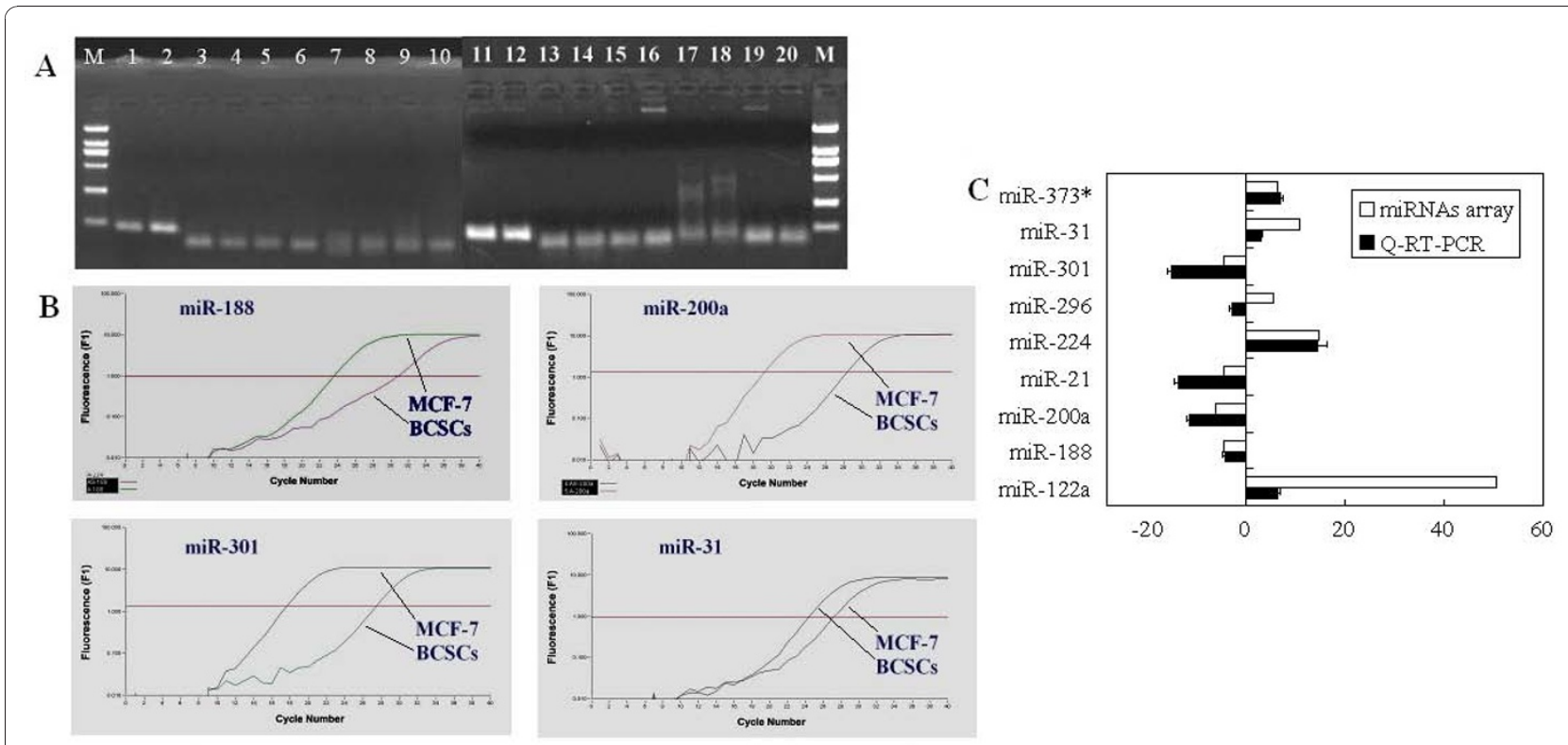

Figure 3 Q-RT-PCR verification of miRNA expression. Gel electrophoresis showed clear and specific bands for all the Q-RT-PCR reactions (A). The amplification curves in the PCR reactions were also clear. Parts of the amplification curves for miR-188, miR-200a miR-301 and miR-31 are shown (B). Ten miRNAs were compared between BCSCs and MCF-7 cells by Q-RT-PCR. Eight of the nine miRNAs tested by real-time RT-PCR gave results consistent with the microarray data, except miR-296, indicating a concordance rate of $88.89 \%$ (C).

which is expressed in MCF-7 cells, may be one of the causes of high expression of the drug-metabolising enzyme CYP1B1 in cancerous tissues [14]. Finally, as a tumor suppressor in breast cancer cells, miR-17-5p regulates breast cancer cell proliferation by inhibiting the translation of AIB1 mRNA [15].

Research on the roles of BCSC-related miRNAs in breast cancer has great significance. Ponti [16] isolated tumorigenic breast cancer cells with stem/progenitor cell properties from a breast cancer cell line, and Huang [17] screened side population (SP) cells from a breast cancer cell line. Here, we investigated the miRNA expression profile of the $\mathrm{ESA}^{+} \mathrm{CD} 44^{+} \mathrm{CD} 24^{-/ \text {Low }}$ subpopulation from the MCF-7 cell line. Real-time RT-PCR was repeated three times, and the results were concordant with microarray data for the miRNA expression profiles of BCSCs.

Recently, a few studies have reported miRNA expression in BCSCs. Shimono [18] found that 37 miRNAs were upregulated or downregulated in BCSCs compared to nontumorigenic breast cancer cells. Three clusters, miR-200c-141, miR-200b-200a-429, and miR-183-96182 , were downregulated in human BCSCs. MiR-200c was shown to be overexpressed in MCF-7 cells, leading to reduced expression of transcription factor 8 and increased expression of E-cadherin [19]. Furthermore,

Table 2 Verification The microarray data were verified by Q-RT-PCR

\begin{tabular}{|c|c|c|c|c|c|c|c|c|}
\hline Name & E & $\mathrm{CT}(\mathrm{BCSCs})$ & CT(MCF-7) & $\begin{array}{c}\Delta C T \\
\text { (BCSCs-MCF7) }\end{array}$ & $\begin{array}{c}\mathrm{RQ} \\
(\mathrm{BCSCs} / \mathrm{U} 6)\end{array}$ & $\begin{array}{c}\mathrm{RQ} \\
\text { (MCF-7/U6) }\end{array}$ & $\begin{array}{c}\mathrm{RQ} \\
\text { (BCSCs/MCF7) }\end{array}$ & $\begin{array}{c}\text { Chip } \\
\text { (BCSCs/MCF7) }\end{array}$ \\
\hline U6 RNA & $1.893 \pm 0.087$ & $18.307 \pm 0.163$ & $15.003 \pm 0.227$ & $3.303 \pm 0.297$ & & & $8.154 \pm 0.516$ & \\
\hline miR-122a & $1.885 \pm 0.098$ & $23.650 \pm 2.810$ & $23.253 \pm 2.812$ & $0.397 \pm 0.031$ & $0.041 \pm 0.007$ & $0.006 \pm 0.001$ & $6.344 \pm 0.402$ & 50.414 \\
\hline miR-188 & $1.766 \pm 0.036$ & $31.103 \pm 0.539$ & $24.795 \pm 0.508$ & $6.308 \pm 0.129$ & $0.004 \pm 0.003$ & $0.015 \pm 0.001$ & $0.226 \pm 0.513$ & 0.207 \\
\hline miR-200a & $1.900 \pm 0.074$ & $28.387 \pm 0.261$ & $21.253 \pm 0.632$ & $7.134 \pm 0.652$ & $0.002 \pm 0.001$ & $0.021 \pm 0.017$ & $0.086 \pm 0.514$ & 0.159 \\
\hline miR-21 & $1.899 \pm 0.011$ & $24.657 \pm 1.325$ & $17.263 \pm 1.435$ & $7.393 \pm 0.195$ & $0.016 \pm 0.003$ & $0.226 \pm 0.051$ & $0.071 \pm 0.503$ & 0.211 \\
\hline miR-224 & $1.683 \pm 0.065$ & $32.437 \pm 0.400$ & $33.497 \pm 0.624$ & $-1.060 \pm 0.288$ & $0.011 \pm 0.001$ & $0.001 \pm 0.000$ & $14.175 \pm 2.033$ & 14.491 \\
\hline miR-296 & $1.905 \pm 0.025$ & $27.237 \pm 0.291$ & $22.247 \pm 0.468$ & $4.990 \pm 0.255$ & $0.003 \pm 0.001$ & $0.009 \pm 0.003$ & $0.334 \pm 0.587$ & 5.242 \\
\hline miR-301 & $1.873 \pm 0.017$ & $27.487 \pm 0.476$ & $19.791 \pm 0.619$ & $7.696 \pm 0.179$ & $0.005 \pm 0.004$ & $0.081 \pm 0.006$ & $0.066 \pm 1.008$ & 0.205 \\
\hline miR-31 & $1.817 \pm 0.027$ & $27.397 \pm 0.448$ & $25.613 \pm 0.634$ & $1.783 \pm 0.210$ & $0.013 \pm 0.001$ & $0.005 \pm 0.000$ & $2.816 \pm 0.328$ & 10.700 \\
\hline miR-373* & $1.902 \pm 0.040$ & $24.370 \pm 1.438$ & $24.060 \pm 1.404$ & $0.310 \pm 0.096$ & $0.019 \pm 0.001$ & $0.003 \pm 0.000$ & $6.684 \pm 0.548$ & 6.183 \\
\hline miR-200C & $1.888 \pm 0.053$ & $24.513 \pm 0.658$ & $19.527 \pm 0.938$ & $4.987 \pm 0.290$ & $0.032 \pm 0.042$ & $0.100 \pm 0.013$ & $0.345 \pm 0.531$ & 1.720 \\
\hline
\end{tabular}


the downregulation of Let-7 miRNAs rather than miR-200C was previously reported for human BCSCs [20]. Let-7 regulates multiple breast cancer stem cell properties by silencing more than one target, and Let-7 miRNAs are markedly reduced in BCSCs and increase with differentiation.

We obtained miRNA expression profiles of BCSCs, providing a substantial basis for exploring the role of miRNAs in maintaining stem cell properties and the biological functions of BCSCs. Compared with previous reports, we found that miR-200C expression was about 3-fold lower in BCSCs than in MCF-7 cells as determined by Q-RT-PCR. Little change was observed in the expression of Let-7 family members, however, between BCSCs and MCF-7 cells, with the exception of Let-7e (data not shown). The discrepancies in Let-7 and miR$200 \mathrm{C}$ expression between studies might be related to differences in tumor histology or the genetic backgrounds of the cell lines analysed. We also detected the expression of some predicted miRNAs in the BCSCs. Given that the existence of predicted miRNAs has yet to be validated, no accurate miRNA sequence could be used to synthesise accurate primers, making real-time RT-PCR verification unavailable. Further study of the functions of these characteristic BCSC miRNAs will facilitate research into the roles of miRNAs in breast cancer.

Bioinformatic analysis and prediction programs have been the primary methods used to explore the function of miRNAs $[21,22]$. The genes possibly regulated by these characteristic BCSC miRNAs are involved in both tumorigenesis and stem cell maintenance. For example, miR-122a has been reported to be specific to liver tissue $[23,24]$; however, our results showed upregulation of miR-122a in BCSCs. The microarray data were verified by Q-RT-PCR. Furthermore, miR-122a was also detected in MCF-7 cells in the Ambion dataset. Bioinformatic analysis showed that the potential targets of miR-122a include several cancer-related genes. In previous reports, it has been shown that miR-122a plays a role in the genesis of hepatocellular carcinoma by blocking cyclin G1 expression [25]. Another study found that G3BP2, one of the potential targets of miR-122a, was more highly expressed in breast cancer tissue than in paraneoplastic tissue [26-28]. These studies indicate that miR-122a is likely to be an important gene regulatory factor in cancer cells, even cancer stem cells. Another example is miR21 , which has been reported to have extensive roles and is expressed in embryonic stem cells [29], neuronal cells [30] and several tumor tissues [31,32]. Previous studies have demonstrated that as an oncogene, miR-21 targets the tumor suppressor gene
Tropomyosin 1 (TPM1)* and may indirectly regulate genes such as the proto-oncogene bcl-2, thus modulating tumorigenesis [33,34]. In this study, miR-21 expression was lower in BCSCs than in MCF-7 cells. Interestingly, target analysis of miR-21 revealed two classes of genes with opposite functions, e.g., PLAG1 (pleiomorphic adenoma gene 1) and PDCD4 (Programmed cell death 4). As a cancer-promoting gene, PLAG1 plays an essential role in the processes of adenocarcinoma formation and malignant transformation in various types of tumors [35], whereas PDCD4 is a tumor suppressor gene that inhibits neoplastic transformation and tumor cell invasion and facilitates apoptosis [36]. Several recent studies have shown that the tumor suppressor PDCD4 is a target of miR-21 [37-39]. Nevertheless, the question remains whether PLAG1 is likely to be a target of miR-21. Moreover, the potential target genes of miR-21 include several oncogenes such as RAB11A, RAB6A, RAB6C, RASGRP1, RHOB and RASA1, etc. Are these genes the true targets of miR-21? What are the mechanisms of their involvement in the genesis of breast cancer? These intriguing questions remain to be answered.

Furthermore, the prediction of potential targets for other BCSC-related miRNAs indicated overlap between the targets of different miRNAs. For example, PLAG1 was a potential target for both miR-224 and miR-200a, and the expression of miR-200a was lower in BCSCs than in MCF-7 cells. In contrast, the expression of miR224 was higher in BCSCs than in MCF-7 cells. It is likely that the miRNAs that are over-expressed or under-expressed in BCSCs may regulate common target genes and form a miRNA gene network by cooperating or competing with each other to regulate the development of BCSCs.

Moreover, miR-301, miR-296, miR-21 and miR-373* have been reported to be expressed in human embryonic stem cells and other stem cells, indicating that these miRNAs may play a constitutive role in maintaining the biological characteristics of stem cells [40,41]. Future work should include verification of the potential targets of all of the BCSC-related miRNAs identified here.

\section{Conclusions}

Here, we investigated the miRNA expression profile of the $\mathrm{ESA}^{+} \mathrm{CD} 44^{+} \mathrm{CD} 24^{-/ \text {Low }}$ BCSC subpopulation from the MCF-7 cell line. Our identification of BCSCrelated miRNAs should be a starting point to explore the functions of these miRNAs, adding a new dimension to our understanding of the complex picture of $\mathrm{BCSCs}$ and assisting cancer biologists and clinical oncologists in designing and testing novel therapeutic strategies. 


\section{Additional material}

Additional file 1: Figure S1- MiRNA microarray for MCF-7 cells \& BCSCs. The figure shows one array of the two hybridisations for MCF-7 cells \& BCSCs. a and b show microarrays for MCF-7 cells, and $c$ and d show microarrays for BCSC cells. Table S1-MiRNAs microarray- based miRNAs expression profile of MCF-7 cells (signal value $\geq 800$ ). The table shows the miRNAs expression profile of MCF-7 cells obtained through miRNAs microarray. Table S2- MiRNAs microarray- based miRNAs expression profile of ESA+CD44+CD24-/low cells (signal value $\mathbf{2 0 0 0}$ ). The table shows the miRNAs expression profile of ESA + CD44+CD24-/low cells obtained through miRNAs microarray. Table S3MiRNA target prediction. The table shows predicted targets for miR-21 and miR-122a, and the primary functions of the target genes. Table S4MiRNAs expression profile of MCF-7 cell from Ambion (signal value $\geq++$ ). The table shows MiRNAs expression profile of MCF-7 cells detected by Ambion.

\section{Acknowledgements}

This work was supported by grant from National Science Foundation of China (to Jian-guo Sun) (NO. 30772108), Postdoctoral Science Foundation of China (to Jian-guo Sun) (NO. 30772108), the Strategic Scientific Project Foundation of the Eleventh Five-Year Plan for Scientific and Technological Development of PLA (to Zheng-tang Chen) (NO. 06G069) and the National High Technology R\&D Program (2008AA02Z104). We give special thanks to Prof. Sodmergen (College of Life Sciences, Peking University) for help and support. We also thank Dr Liying Du (College of life sciences, Peking University) for her expertise in FACS.

\section{Author details}

'Cancer Institute of People's Liberation Army, Xinqiao Hospital, Third Military Medical University, Chongqing, 400037, China. ${ }^{2}$ Department of Biochemistry and Molecular Biology, Third Military Medical University, Chongqing, 400038, China. ${ }^{3}$ Department of Anatomy, College of Medicine, Third Military Medical University, Chongqing, 400038, PR China.

\section{Authors' contributions}

JS conceived of the study, and participated in its design and drafted the manuscript. RL participated in the study design and carried out the FACS and microarray analysis. JQ and JJ participated in the Colony-forming assay and performed human breast cancer xenograft assay. XW and YD performed the Immunostaining. FC and PH participated in the microarray analysis. QX and ZW performed the Real-time RT-PCR. DL helped with the statistical analysis and manuscript drafting.ZC and SZ conceived of the study, and participated in its design and coordination and helped to draft the manuscript. All authors have read and approved the final manuscript.

\section{Competing interests}

The authors declare that they have no competing interests.

Received: 21 August 2010 Accepted: 31 December 2010 Published: 31 December 2010

\section{References}

1. Al-Hajj M, Wicha MS, Benito-Hernandez A, Morrison SJ, Clarke MF: Prospective identification of tumorigenic breast cancer cells. Proc Natl Acad Sci USA 2003, 100(7):3983-3988.

2. Harrison H, Farnie G, Howell SJ, Rock RE, Stylianou S, Brennan KR, Bundred NJ, Clarke RB: Regulation of breast cancer stem cell activity by signaling through the Notch4 receptor. Cancer Res 2010, 70(2):709-18.

3. Guo J, Zhou J, Ying X, Men Y, Li RJ, Zhang Y, Du J, Tian W, Yao HJ, Wang XX, Ju RJ, Lu WL: Effects of stealth liposomal daunorubicin plus tamoxifen on the breast cancer and cancer stem cells. J Pharm Pharm Sci 2010, 13(2):136-51

4. Shcherbata HR, Hatfield S, Ward EJ, Reynolds S, Fischer KA, Ruohola-Baker H: The MicroRNA pathway plays a regulatory role in stem cell division. Cell Cycle 2006, 5(2):172-175.
5. Griffiths-Jones S, Saini HK, van Dongen S, Enright AJ: Tools for microRNA genomics. Nucleic Acids Res 2008, 36:D154-D158.

6. He L, Thomson JM, Hemann MT, Hernando-Monge E, Mu D, Goodson S, Powers S, Cordon-Cardo C, Lowe SW, Hannon GJ, Hammond SMA: MicroRNA polycistron as a potential human oncogene. Nature 2005, 435(7043):828-833

7. Iorio MV, Ferracin M, Liu CG, Veronese A, Spizzo R, Sabbioni S, Magri E, Pedriali M, Fabbri M, Campiglio M, Ménard S, Palazzo JP, Rosenberg A, Musiani P, Volinia S, Nenci I, Calin GA, Querzoli P, Negrini M, Croce CM: MicroRNA gene expression deregulation in human breast cancer. Cancer Res 2005, 65(16):7065-7070.

8. Gregory Rl, Shiekhattar R: MicroRNA biogenesis and cancer. Cancer Res 2005, 65(9):3509-3512.

9. Liao R, Sun J, Zhang L, Lou G, Chen M, Zhou D, Chen Z, Zhang S: MicroRNAs play a role in the development of human hematopoietic stem cells. J Cell Biochem 2008, 104(3):805-817.

10. Xie X, Lu J, Kulbokas EJ, Golub TR, Mootha V, Lindblad-Toh K, Lander ES, Kellis M: Systematic discovery of regulatory motifs in human promoters and 3' UTRs by comparison of several mammals. Nature 2005, 434(7031):338-345

11. Chen C, Ridzon DA, Broomer AJ, Zhou Z, Lee DH, Nguyen TJ, Barbisin M, Xu NL, Mahuvakar VR, Andersen MR, Lao KQ, Livak KJ, Guegler KJ: Real-time quantification of microRNAs by stem-loop RT-PCR. Nucleic Acids Res 2005, 33(20):e179

12. Adams BD, Furneaux $H$, White BA: The micro-ribonucleic acid (miRNA) miR-206 targets the human estrogen receptor-alpha (ERalpha) and represses ERalpha messenger RNA and protein expression in breast cancer cell lines. Mol Endocrinol 2007, 21(5):1132-1147.

13. Scott GK, Goga A, Bhaumik D, Berger CE, Sullivan CS, Benz CC: Coordinate suppression of ERBB2 and ERBB3 by enforced expression of micro-RNA miR-125a or miR-125b. J Biol Chem 2007, 282(2):1479-1486.

14. Tsuchiya Y, Nakajima M, Takagi S, Taniya T, Yokoi T: MicroRNA regulates the expression of human cytochrome P450 1B1. Cancer Res 2006, 66(18):9090-9098.

15. Hossain A, Kuo MT, Saunders GF: Mir-17-5p regulates breast cancer cell proliferation by inhibiting translation of AIB1 mRNA. Mol Cell Biol 2006, 26(21):8191-8201.

16. Ponti D, Costa A, Zaffaroni N, Pratesi G, Petrangolini G, Coradini D, Pilotti S, Pierotti MA, Daidone MG: Isolation and in vitro propagation of tumorigenic breast cancer cells with stem/progenitor cell properties. Cancer Res 2005, 65(13):5506-5511.

17. Huang $M, L i Y, W u$ G, Zhang F: Whole Genome Expression Profiling Reveals a Significant Role for the Cell Junction and Apoptosis Pathways in Breast Cancer Stem Cells. Mol Biotechnol 2010, 45(1):39-48.

18. Shimono Y, Zabala M, Cho RW, Lobo N, Dalerba P, Qian D, Diehn M, Liu H, Panula SP, Chiao E, Dirbas FM, Somlo G, Pera RA, Lao K, Clarke MF: Downregulation of miRNA-200c links breast cancer stem cells with normal stem cells. Cell 2009, 138(3):592-603.

19. Hurteau GJ, Carlson JA, Spivack SD, Brock GJ: Overexpression of the microRNA miR-200c leads to reduced expression of transcription factor 8 and increased expression of E-cadherin. Cancer Res 2007, 67(17):7972-7976.

20. Yu F, Yao H, Zhu P, Zhang X, Pan Q, Gong C, Huang Y, Hu X, Su F, Lieberman J, Song E: let-7 regulates self renewal and tumorigenicity of breast cancer cells. Cell 2007, 131(6):1109-1123.

21. Bentwich I: Prediction and validation of microRNAs and their targets. FEBS Lett 2005, 579(26):5904-5910.

22. Doran J, Strauss WM: Bio-informatic trends for the determination of miRNAs-target interactions in mammals. DNA Cell Biol 2007, 26(5):353-360.

23. Lagos-Quintana M, Rauhut R, Yalcin A, Meyer J, Lendeckel W, Tuschl T: Identification of tissue-specific microRNAs from mouse. Curr Biol 2002 12(9):735-739.

24. Fu H, Tie $Y$, Xu C, Zhang Z, Zhu J, Shi $Y$, Jiang $H$, Sun Z, Zheng $X$ : Identification of human fetal liver miRNAs by a novel method. FEBS Lett 2005, 579(17):3849-3854

25. Gramantieri L, Ferracin M, Fornari F, Veronese A, Sabbioni S, Liu CG, Calin GA, Giovannini C, Ferrazzi E, Grazi GL, Croce CM, Bolondi L, Negrini M: Cyclin G1 is a target of miR-122a, a microRNA frequently downregulated in human hepatocellular carcinoma. Cancer Res 2007, 67(13):6092-6099. 
26. Kim MM, Wiederschain D, Kennedy D, Hansen E, Yuan ZM: Modulation of p53 and MDM2 activity by novel interaction with Ras-GAP binding proteins (G3BP). Oncogene 2007, 26(29):4209-4215.

27. French J, Stirling R, Walsh M, Kennedy HD: The expression of Ras-GTPase activating protein $\mathrm{SH} 3$ domain-binding proteins, G3BPs, in human breast cancers. Histochem J 2002, 34(5):223-231.

28. Prigent M, Barlat I, Langen H, Dargemont C: IkappaBalpha and IkappaBalpha/NF-kappa B complexes are retained in the cytoplasm through interaction with a novel partner, RasGAP SH3-binding protein 2. J Biol Chem 2000, 275(46):36441-36449.

29. Suh MR, Lee Y, Kim JY, Kim SK, Moon SH, Lee JY, Cha KY, Chung HM, Yoon HS, Moon SY, Kim VN, Kim KS: Human embryonic stem cells express a unique set of microRNAs. Dev Biol 2004, 270(2):488-498.

30. Dostie J, Mourelatos Z, Yang M, Sharma A, Dreyfuss G: Numerous microRNPs in neuronal cells containing novel microRNAs. RNA 2003, 9(2):180-186.

31. Kasashima K, Nakamura Y, Kozu T: Altered expression profiles of microRNAs during TPA-induced differentiation of HL-60 cells. Biochem Biophys Res Commun 2004, 322(2):403-410.

32. Michael MZ, O'Connor SM, van Holst Pellekaan NG, Young GP, James RJ: Reduced accumulation of specific microRNAs in colorectal neoplasia. Mol Cancer Res 2003, 1(12):882-891.

33. Zhu S, Si ML, Wu H, Mo YY: MicroRNA-21 targets the tumor suppressor gene tropomyosin 1 (TPM1). J Biol Chem 2007, 282(19):14328-14336.

34. Si ML, Zhu S, Wu H, Lu Z, Wu F, Mo YY: miR-21-mediated tumor growth. Oncogene 2007, 26(19):2799-2803.

35. Van Dyck F, Scroyen I, Declerca J, Sciot R, Kahn B, Lijnen R, Van de Ven WJ: aP2-Cre-mediated expression activation of an oncogenic PLAG1 transgene results in cavernous angiomatosis in mice. Int J Oncol 2008, 32(1):33-40.

36. Nieves-Alicea R, Colburn NH, Simeone AM, Tari AM: Programmed Cell Death 4 inhibits breast cancer cell invasion by increasing Tissue Inhibitor of Metalloproteinases-2 expression. Breast Cancer Res Treat 2009, 114(2):203-209.

37. Frankel LB, Christoffersen NR, Jacobsen A, Lindow M, Krogh A, Lund AH: Programmed cell death 4 (PDCD4) is an important functional target of the microRNA miR-21 in breast cancer cells. J Biol Chem 2008, 283(2):1026-1033.

38. Lakshmipathy U, Love B, Goff LA, Jörnsten R, Graichen R, Hart RP, Chesnut JD: MicroRNA Expression Pattern of Undifferentiated and Differentiated Human Embryonic Stem Cells. Stem Cells Dev 2007, 16(6):1003-1016

39. Bourguignon LY, Spevak CC, Wong G, Xia W, Gilad E: Hyaluronan-CD44 interaction with protein kinase $C$ (epsilon) promotes oncogenic signaling by the stem cell marker Nanog and the Production of microRNA-21, leading to down-regulation of the tumor suppressor protein PDCD4, anti-apoptosis, and chemotherapy resistance in breast tumor cells. J Biol Chem 2009, 284(39):26533-26546.

40. Houbaviy HB, Murray MF, Sharp PA: Embryonic stem cell-specific MicroRNAs. Dev Cell 2003, 5(2):351-358.

41. Greco SJ, Rameshwar P: MicroRNAs regulate synthesis of the neurotransmitter substance $P$ in human mesenchymal stem cell-derived neuronal cells. Proc Natl Acad Sci USA 2007, 104(39):15484-15489.

doi:10.1186/1756-9966-29-174

Cite this article as: Sun et al:: Microarray-based analysis of microRNA expression in breast cancer stem cells. Journal of Experimental \& Clinical Cancer Research 2010 29:174.

\section{Submit your next manuscript to BioMed Central and take full advantage of:}

- Convenient online submission

- Thorough peer review

- No space constraints or color figure charges

- Immediate publication on acceptance

- Inclusion in PubMed, CAS, Scopus and Google Scholar

- Research which is freely available for redistribution

Submit your manuscript at www.biomedcentral.com/submit
Biomed Central 